\title{
The Origins of Human Rights Regimes: Democratic Delegation in Postwar Europe
}

\author{
Andrew Moravcsik
}

The fiftieth anniversary of the UN Universal Declaration on Human Rights marks an appropriate moment to reconsider the reasons why governments construct international regimes to adjudicate and enforce human rights. Such regimes include those established under the European Convention for the Protection of Human Rights and Fundamental Freedoms (ECHR), the Inter-American Convention on Human Rights, and the UN Covenant on Civil and Political Rights.

These arrangements differ from most other forms of institutionalized international cooperation in both their ends and their means. Unlike international institutions governing trade, monetary, environmental, or security policy, international human rights institutions are not designed primarily to regulate policy externalities arising from societal interactions across borders, but to hold governments accountable for purely internal activities. In contrast to most international regimes, moreover, human rights regimes are not generally enforced by interstate action. Although most arrangements formally empower governments to challenge one another, such challenges almost never occur. The distinctiveness of such regimes lies instead in their empowerment of individual citizens to bring suit to challenge the domestic activities of their own government. Independent courts and commissions attached to such regimes often respond to such individual claims by judging that the application of domestic rules or legislation violates international commitments, even where such legislation has been

For detailed suggestions and criticisms I am grateful to Gary Bass, George Bermann, Nancy Kokaz, Ronald Mitchell, Gerald Neuman, Daniel Nexon, Robert Paarlberg, Pasquale Pasquino, Kathryn Sikkink, Brian Simpson, and Henry Steiner, as well as Henning Boekle, John Ferejohn, Alexandra Filindra, Mary Ann Glendon, Virginie Guiraudon, John Ikenberry, Anne-Marie Slaughter, and participants in colloquia at Columbia University, Harvard University, New York University, the University of Oregon, the University of Pennsylvania, Princeton University, Rutgers University, and the 1999 Annual Convention of the American Political Science Association. I thank Jorge Dominguez, Stephen Holmes, and Richard Tuck for particular guidance, and Monique Hofkin, Alejandro Lorite, Alexandra Samuel, and Ilya Somin for able research assistance. Finally, I acknowledge financial and logistical support from the Weatherhead Center for International Affairs, the Center for European Studies at Harvard University, and the Center for European Studies at New York University. For an earlier version of this article with more detailed documentation, see Moravcsik 1998b. 
enacted and enforced through fully democratic procedures consistent with the domestic rule of law. Arrangements to adjudicate human rights internationally thus pose a fundamental challenge not just to the Westphalian ideal of state sovereignty that underlies realist international relations theory and classical international law but alsothough less-frequently noted - to liberal ideals of direct democratic legitimacy and self-determination. The postwar emergence of these arrangements has rightly been characterized as the most "radical development in the whole history of international law."1

Consider, for example, the ECHR, established under the auspices of the Council of Europe and based in Strasbourg, France. The ECHR system is widely accepted as the "most advanced and effective" international regime for formally enforcing human rights in the world today. ${ }^{2}$ Since 1953, when the ECHR came into force, it has sought to define and protect an explicit set of civil and political rights for all persons within the jurisdiction of its member states, whether those individuals are aliens, refugees, stateless persons, or citizens. It initially established a Commission on Human Rights to review petitions. ${ }^{3}$ The Commission could investigate the case, seek to settle it, or forward it under certain circumstances to a court of human rights, whose decisions governments are legally bound to follow. Two optional clauses of the ECHR, Articles 25 and 46, were subsequently adopted by all member states; they permit individual and state-to-state petitions and recognize the compulsory jurisdiction of the court. Many European governments have subsequently incorporated the convention into domestic law, directly or indirectly. For these reasons, the ECHR Court is right to proclaim the convention "a constitutional document of European public order." 4

Over the last half-century, analysts agree, the legal commitments and enforcement mechanisms entered into under the ECHR have established "effective supranational adjudication" in Europe. Compliance is so consistent that ECHR judgments are now, in the words of two leading international legal scholars, "as effective as those of any domestic court." 5 In hundreds of cases where an explicit decision has been taken or a

1. See Humphrey 1974, 205, 208-209; Krasner 1995; and Falk 1981, 4, 153-83.

2. Petitions could be judged admissible if they meet several criteria, most importantly the prior exhaustion of domestic remedies. Henkin et al. 1999, 551. In this article I am not concerned with purely rhetorical human rights documents, such as the UN Universal Declaration, but solely with enforceable commitments. Rights imply remedies, without which the former are of little utility. Unsurprisingly, hypocrisy in signing declarations without mechanisms for direct enforcement appears to be without significant cost, regardless of a country's domestic policies. While liberal democracies may be more likely to sign such declarations, they are hardly alone in their willingness. At the height of the Cold War, the United States, the USSR, China, Iran, and dozens of other countries found ways to work around their differences and signed the wide-ranging UN Declaration on Human Rights. Some analysts conjecture that in the longer term such declarations help mobilize societal opposition to nondemocratic governments, for example, through the Inter-American and Helsinki CSCE-OSCE regimes. Yet it is telling that those interested in effective enforcement have consistently sought to establish mechanisms for raising and resolving disputes, as with the UN Covenants in the 1960s and the CSCE Vienna mechanism in 1989. Brett 1996.

3. See Janis, Kay, and Bradley 1995; Robertson and Merrills 1993; and van Dijk and van Hoof 1998. With reforms that came into effect in 1998, the commission was abolished and its activities turned over to the court itself, with similar criteria for admitting claims.

4. Loizidou v. Turkey, 310 Eur. Ct. H.R. (ser. A, 1995), 27.

5. Helfer and Slaughter 1997, 283, who draw on Shapiro 1981, 7, 26-36. 
"friendly settlement" reached-including matters of criminal procedure, penal codes and the treatment of prisoners, vagrancy legislation, civil codes, systems of legal aid fees and civil legal advice, the rights of illegitimate children, military codes, expropriation policies, systems of awarding building permits, treatment of the mentally ill, reformatory centers, wiretapping, and censorship of the press-governments have amended legislation, granted administrative remedies, reopened judicial proceedings, or paid monetary damages to individuals whose treaty rights were violated. ${ }^{6}$ When the court recently ruled that exclusion of homosexuals from the British armed forces violated the ECHR, the British government immediately announced its intention to comply. In countless additional cases, litigants have successfully pleaded the ECHR before domestic courts. ${ }^{7}$

There is a real theoretical puzzle here. Why would any government, democratic or dictatorial, favor establishing an effective independent international authority, the sole purpose of which is to constrain its domestic sovereignty in such an unprecedentedly invasive and overtly nonmajoritarian manner?

To answer questions such as this, political scientists tend to espouse either a realist or an ideational explanation for the emergence and expansion of formal human rights regimes. Democratic governments and transnationally active members of democratic civil societies either coerce other governments to accept human rights norms (the realist view) or persuade other governments to do so (the ideational view). Some scholars espouse both positions at once, arguing that powerful democracies are persuaded for essentially idealistic reasons to coerce others to respect human rights norms.

Such realist and ideational conjectures, though popular among scholars, rest on a remarkably thin empirical foundation. Historians have conducted almost no detailed case studies of the formation of international human rights regimes. Only the UN system - a notably weak regime-has been the subject of significant research, and this body of work focuses on rhetorical statements, such as the UN Declaration, rather than arrangements for adjudication and enforcement. ${ }^{8}$ Such analyses, moreover, tend to accept uncritically the ex post conjectures of practitioners and commentators.

This article contains the first systematic empirical test of competing theories of the establishment of formal international human rights regimes. It does so by examining the negotiations to establish the ECHR in 1949-50. I argue that the primary proponents of binding international human rights commitments in postwar Europe were neither great powers, as realist theory would have it, nor governments and transnational groups based in long-established liberal democracies, as the ideational account would have it. Although established democracies supported certain human rights declarations, they allied with dictatorships and transitional regimes in opposition to

6. Carter and Trimble 1995, 309.

7. On domestic incorporation, see Polakiewicz and Jacob-Foltzer 1991; Drzemczewski 1983, 11-12; and Merrills 1993.

8. For the best of these, see Morsink 1999. 
reciprocally binding human rights enforcement - a seldom-noted tendency for which realists and ideational theorists have no explanation. The primary proponents of reciprocally binding human rights obligations were instead the governments of newly established democracies.

This curious pattern is explicable only if we adopt a different theoretical starting point: the domestic political self-interest of national governments. Establishing an international human rights regime is an act of political delegation akin to establishing a domestic court or administrative agency. From a "republican liberal" perspectiveone related to institutional variants of "democratic peace" theory as well as to the analysis of "two-level games" and public-choice theories of delegation-creating a quasi-independent judicial body is a tactic used by governments to "lock in" and consolidate democratic institutions, thereby enhancing their credibility and stability vis-à-vis nondemocratic political threats. In sum, governments turn to international enforcement when an international commitment effectively enforces the policy preferences of a particular government at a particular point in time against future domestic political alternatives.

I argue that governments will resort to this tactic when the benefits of reducing future political uncertainty outweigh the "sovereignty costs" of membership. It follows that "self-binding" is of most use to newly established democracies, which have the greatest interest in further stabilizing the domestic political status quo against nondemocratic threats. We should therefore observe them leading the move to enforce human rights multilaterally, whereas established democracies have an incentive to offer lukewarm support at best. In the case of the ECHR, this theoretical approach best explains the cross-national pattern of support for binding norms, the tactics governments employed, and the archival record of public rhetoric and confidential domestic deliberations.

The implications of this approach go well beyond postwar European human rights. The logic of "locking in" credible domestic policies through international commitments can be generalized to other human rights regimes-including the recent International Criminal Court—and unilateral human rights policies, not least the apparently anomalous behavior of the United States, as well as to other issue areas in world politics, regardless of whether their substantive content is "liberal." The latter include the stabilization of autocratic regimes under the Concert of Europe and Comintern, and the coordination of monetary and trade policies.

\section{Existing Theories of International Human Rights Cooperation}

Existing scholarship seeking to explain why national governments establish and enforce formal international human rights norms focuses on two modes of interstate interaction: coercion and normative persuasion. Respectively, these define distinctive "realist" and "ideational" explanations for the emergence of human rights re- 
gimes. Despite being widely viewed as theoretical antitheses, many empirical predictions of these two explanations converge.

\section{Interstate Power: "For Countries at the Top, This Is Predictable"}

Realist theories of international relations, and thus of the origin of human rights regimes, stress the distribution of interstate bargaining power. Governments accept international obligations because they are compelled to do so by great powers, which externalize their ideology - a prediction that follows equally from hegemonic stability theory and conventional realist bargaining theory. ${ }^{9}$ All governments seek to maintain full domestic sovereignty wherever possible. With governments uniformly skeptical of external constraints, the major limitation on cooperation is the cost of coercion or inducement, which is inversely proportional to the concentration of power. Establishment of a binding human rights regime requires, therefore, a hegemonic ("k") group of great powers willing to coerce or induce recalcitrant states to accept, adjust to, and comply with international human rights norms. The greater the concentration of relative power capabilities, the greater the pressure on recalcitrant governments and the more likely is an international regime to form and prosper.

Precise formulations of the realist argument vary. E. H. Carr, Hans Morgenthau, and other classical realists maintain that governments employ liberal ideology, including support for human rights, to justify the pursuit of geopolitical interest. ${ }^{10} \mathrm{Jack}$ Donnelly writes of the Inter-American Convention on Human Rights that "much of the explanation [for] the Inter-American human rights regime . . . lies in power, particularly the dominant power of the United States.... [It] is probably best understood in these terms. The United States . . . exercised its hegemonic power to ensure its creation and support its operation." "11 John Ruggie uncharacteristically takes a similar line when he conjectures that human rights regimes will be weaker than nuclear nonproliferation regimes, because the former are of less concern to the core superpower security interests. ${ }^{12}$ Kenneth Waltz asserts that powerful nations invariably seek to impose their views on other nations: "Like some earlier great powers, we [the United States] can identify the presumed duty of the rich and powerful to help others with our own beliefs . . . England claimed to bear the white man's burden; France had its mission civilisatrice. . . For countries at the top, this is predictable behavior.'" 13 Alison Brysk links acceptance of human rights norms to the pressure by

9. Many analysts take the opposite view, namely that great powers tend to oppose strong human rights regimes. One might conjecture that large states have a commitment to sovereignty independent of the substantive issue at stake, or one might assume that great powers believe they can impose human rights on others unilaterally. This view is widely espoused as an explanation for the combined opposition during the 1950s of the United States, the United Kingdom, the USSR, and China to strong UN enforcement. Yet this consensus lacks theoretical underpinnings or empirical support beyond the casual impressions of a few participants. We shall see that the generalization is disconfirmed by the case of the ECHR negotiations. Compare Samnøy 1993, 76.

10. See Carr 1946; and Morgenthau 1960.

11. See Donnelly 1986, 625, also 637-38; and Ruggie 1983, 99.

12. Ruggie 1983, 104.

13. Waltz 1979, 200. See also Krasner 1992. 
TABLE 1. Establishing human rights regimes: Theories, causal mechanisms, and predictions

\begin{tabular}{|c|c|c|c|}
\hline & Realism & $\begin{array}{c}\text { Ideational } \\
\text { theory }\end{array}$ & $\begin{array}{l}\text { Republican } \\
\text { liberalism }\end{array}$ \\
\hline Motivations and tactics & $\begin{array}{l}\text { Great powers employ } \\
\text { coercion or induce- } \\
\text { ment to unilaterally } \\
\text { extend national ideals } \\
\text { derived from national } \\
\text { pride or geopolitical } \\
\text { self-interest. } \\
\text { Smaller states defend } \\
\text { their sovereignty. }\end{array}$ & $\begin{array}{l}\text { Altruistic governments } \\
\text { and groups in estab- } \\
\text { lished democracies } \\
\text { seek to extend per- } \\
\text { ceived universal } \\
\text { norms. } \\
\text { Less-democratic states } \\
\text { are socialized or per- } \\
\text { suaded through } \\
\text { existing transnational } \\
\text { networks (the "logic } \\
\text { of appropriateness"'). }\end{array}$ & $\begin{array}{l}\text { Governments seek to } \\
\text { prevent domestic } \\
\text { oppression and inter- } \\
\text { national conflict } \\
\text { through international } \\
\text { symbols, standards, } \\
\text { and procedures that } \\
\text { secure domestic } \\
\text { democracy. They are } \\
\text { constrained by fear } \\
\text { that domestic laws } \\
\text { might be struck } \\
\text { down. International } \\
\text { agreement reflects } \\
\text { convergent interests. }\end{array}$ \\
\hline $\begin{array}{l}\text { Predicted national pref- } \\
\text { erences on compul- } \\
\text { sory commitments }\end{array}$ & $\begin{array}{l}\text { Supporters are led by } \\
\text { democratic great } \\
\text { powers. The weaker } \\
\text { the state, the less } \\
\text { support we observe. }\end{array}$ & $\begin{array}{l}\text { Supporters are led by } \\
\text { societal groups and } \\
\text { governments in the } \\
\text { most democratic } \\
\text { states. The less estab- } \\
\text { lished the democracy, } \\
\text { the less support we } \\
\text { observe. }\end{array}$ & $\begin{array}{l}\text { Supporters are led by } \\
\text { newly established } \\
\text { democracies. Estab- } \\
\text { lished democracies } \\
\text { accept only optional } \\
\text { or rhetorical commit- } \\
\text { ments. Nondemocra- } \\
\text { cies oppose. }\end{array}$ \\
\hline $\begin{array}{l}\text { Predicted variation in } \\
\text { cooperation }\end{array}$ & $\begin{array}{l}\text { Greater concentration } \\
\text { of power in the hands } \\
\text { of great power } \\
\text { democracies } \\
\text { More cost-effective } \\
\text { coercion or induce- } \\
\text { ment } \\
\text { More cooperation. }\end{array}$ & $\begin{array}{l}\text { More attractive norms, } \\
\text { more salient, more } \\
\text { legitimate exemplars, } \\
\text { and the more estab- } \\
\text { lished the transna- } \\
\text { tional networks } \\
\text { More powerful social- } \\
\text { ization effects } \\
\text { More cooperation. }\end{array}$ & $\begin{array}{l}\text { More immediate threats } \\
\text { to democracy } \\
\text { Greater desire to } \\
\text { enhance domestic } \\
\text { stability } \\
\text { More cooperation. }\end{array}$ \\
\hline
\end{tabular}

international financial organizations such as the World Bank, backed by Western donor countries. ${ }^{14}$ These predictions, and those of competing theories, are summarized in the first column of Table 1 .

\section{Normative Persuasion: "The Inescapable Ideological Appeal of Human Rights"}

The most prominent ideational explanations for the emergence and enforcement of human rights regimes look to altruism and the persuasive power of principled ideas. 
Such explanations rest, to that extent, on what used to be termed "utopian" or "idealist" foundations. The essence of such explanations lies in the prominence of idealistic or altruistic motivations for spreading liberal values. ${ }^{15}$ Governments accept binding international human rights norms because they are swayed by the overpowering ideological and normative appeal of the values that underlie them. "The seemingly inescapable ideological appeal of human rights in the postwar world," writes Donnelly, who espouses a wide range of theories, "is an important element in the rise of international human rights regimes." 16

Ideational arguments differ most fundamentally from realist arguments in their reliance on a distinctive conception of interstate interaction. They explicitly reject choice-theoretic foundations and instead stress the transformative power of normative moral discourse itself. In this view, a critical characteristic of political action in this area is that it is "principled" - that is, the altruistic and moral motives of actors have persuasive power in themselves. Accordingly, the most fundamental motivating force behind human rights regimes is not rational adaptation, let alone coercion, but transnational socialization-the "logic of appropriateness." ${ }^{17}$ Many such explanations assert that transformations in actor identities occur though the impact of "principled" nongovernmental organizations (NGOs) on domestic and transnational opinion. ${ }^{18}$ NGOs and publics within established democracies set up transnational networks, epistemic communities, and global discourses of human rights, dedicated to the advancement of a normative discourse of human rights. This in turn mobilizes domestic and transnational civil society at home and abroad, eventually socializing foreign and domestic leaders. ${ }^{19}$

Whence the ideological appeal of human rights? Some scholars look to human moral psychology, regional cultures, or salient historical events, but the most plausible explanation links support for international human rights protection to domestic democracy and commitment to the "rule of law." ${ }^{20}$ In this view, which Thomas Risse terms "liberal constructivism," established democratic governments seek to extend their domestic values abroad and recognize others who do so. The more democratic they are, the more likely their espousal of human rights values. ${ }^{21}$ Charles Kupchan and Clifford Kupchan conjecture that "states willing to submit to the rule of law and civil society are more likely to submit to their analogues internationally." 22 Similarly, Kathryn Sikkink points to the leading role of established democracies in promoting human rights, such as linking Scandinavian support for human rights enforce-

15. Keck and Sikkink 1998, chap. 1-3.

16. Donnelly 1986, 638. On soft power, see Nye 1990.

17. See Finnemore and Sikkink 1998; and Donnelly 1986.

18. See Sikkink 1993; Risse-Kappen 1994; and Finnemore 1996.

19. See, for example, Keck and Sikkink 1998; and Ramirez, Soysal and Shanahan 1997.

20. Russett 1993. For alternative views, see Keck and Sikkink 1998; Sikkink 1993; Sieghart 1983, 26-27; and Ando 1992, 171-72. See also Donnelly 1986; Whitfield 1988, 31, also 28-31; and Drzemczewski 1983, 220.

21. See Risse-Kappen 1996; and Moravcsik 1997. This view is related to the ideational variant of democratic peace theory, in which the democratic peace results from the tendency of liberal governments to externalize their domestic ideals. See Russett 1993.

22. Kupchan and Kupchan 1991, 115-16. 
ment to the salience of social democratic values in their domestic politics. ${ }^{23}$ Thomas Franck asserts that compliance with international law is a function of the normative acceptance of international rules, which in turn reflects (among other things) their consistency with domestic values. ${ }^{24}$ In sum, governments promote norms abroad because they are consistent with universal ideals to which they adhere; governments accept them at home because they are convinced doing so is "appropriate."

The desire to conform to shared ideas and norms of state behavior ("collective expectations about proper behavior for a given identity"), in this view, does not simply regulate state behavior, but constitutes and reconstitutes state identities. ${ }^{25}$ Such theories explicitly distance themselves from explanations that rely on instrumental calculations about the establishment of legitimate domestic governance. ${ }^{26}$ Two leading ideational theorists explicitly reject, for example, the argument I shall introduce later-namely, that governments support human rights regimes to advance partisan and public interest in preventing domestic violence and interstate warfare. In a striking historical conjecture, these analysts assert that in the 1940s and 1950s governments could not possibly have sought human rights regimes to preserve the "democratic peace" because such founding moments "came well before the emergence of the new social knowledge" that undemocratic regimes undermine peace-a collective belief they date to research by liberal international relations theorists in the early 1980s, led by Michael Doyle. ${ }^{27}$ As we shall soon see, this equation of "social knowledge" with academic political science misstates the true origins of human rights regimes because it underestimates the ability of nonacademics to generate a widely accepted, factually grounded—and ultimately accurate—consensus about world politics.

\section{The "New Orthodoxy": A Curious Convergence of Realism and Idealism}

The study of human rights makes unlikely bedfellows. Although realist and ideational theories start from very different assumptions, their predictions about human rights tend to converge. Most existing analyses of human rights regimes rest on an uneasy synthesis of these two explanations. Realists cited earlier tend to argue that human rights norms are expressions of domestic values, not simply propagandistic justifications for the pursuit of national security interests. ${ }^{28}$ Ideational theorists rarely treat socialization (that is, transnational education, imitation, and fundamental norma-

23. Sikkink 1993.

24. Franck 1988.

25. Jepperson, Wendt, and Katzenstein 1996, 54.

26. Finnemore and Sikkink 1998. Thomas Risse has sought to take this further by drawing on Habermasian normative theory as a basis for positive analysis. See Risse 2000 .

27. Keck and Sikkink 1998, 203. See also fn. 68 and accompanying text in this article. Compare Helfer and Slaughter 1997, 331-35.

28. Even if this were the case, the argument would not be entirely realist, since the claim that democratic governments are more likely to side with the West does not necessarily follow from realist theory. Even self-styled realists increasingly concede that societal preferences play an important, often determinant role in alliance formation. For a criticism of this type of realist degeneration, see Legro and Moravcsik 1999. 
tive persuasion) as the sole (or even the primary) mechanism that induces governments to accept formal human rights guarantees. Donnelly argues, for example, that Gramscian "hegemonic ideas . . can be expected to draw acquiescence in relatively weak regimes, but beyond promotional activities (that is, where significant sacrifices of sovereignty are demanded), something more is needed." 29

Many in both schools therefore adopt what Robert Keohane has elsewhere termed the realist "fall-back" position: Public interest groups with idealistic values, perhaps transnationally organized, shape the underlying preferences of democratic great powers, which then deploy their preponderant power to construct and enforce international human rights norms. Idealism explains the position of great powers; realism explains the spread of norms. ${ }^{30}$ In generalizing about human rights regimes, for example, Margaret Keck and Kathryn Sikkink focus extensively on the transcultural attractiveness of ideas and the density of transnational organization (ideational factors) and the vulnerability of targets to sanctions (a realist factor). As we have seen, they explicitly contrast this explanation, however, with an explanation that focuses on domestic institutional and material preconditions, which they reject outright (on theoretical, not empirical grounds) as at most only secondary. ${ }^{31}$

There is thus considerably more convergence in empirical predictions about the source of support for human rights regimes than broad theoretical labels might suggest (see Table 1). Most theories, whether realist or ideational, predict that governments, interest groups, and public opinion in established democratic states spearhead efforts to form and enforce international human rights regimes-and they induce, coerce, or persuade others to go join. Yet, as I discuss in more detail later, this is simply not the case. In postwar Europe, as in the UN during this period, established democracies consistently opposed reciprocally binding human rights obligations and neither coerced nor persuaded anyone else to accept them. Before moving on to the empirical analysis, it is therefore necessary to examine a third explanation for the formation of human rights regimes.

\section{Republican Liberalism: Democratic Peace and Domestic Commitment}

If realist and ideational explanations view the motivations for establishing human rights regimes as involving international coercion or persuasion, a "republican liberal" explanation views them as resulting from instrumental calculations about domestic politics. ${ }^{32}$ In general, republican liberal theories stress the impact of varying

29. Donnelly 1986, 638-39.

30. Ruggie 1983, 98-99. On this sort of realist fall-back or two-step position more generally, see Legro 1996; Moravcsik 1997, 543; Keohane 1986, 183; and Legro and Moravcsik 1999.

31. Keck and Sikkink 1998, 201-209.

32. Liberal international relations theory focuses on state behavior driven by variation in the economic interests and conceptions of public goods provision on the part of societal groups, as well as by the nature of domestic political institutions. The republican liberal label is appropriate to international relations theory debates, though the concern about promoting democracy also has elements of ideational liberal- 
domestic political institutions-in particular, the scope and bias of political representation-on foreign policy. The most prominent among such theories include institutional explanations of the "democratic peace," yet the family of republican liberal theories offers a far wider range of potential explanations, subsuming theories of the role of cartelized elites and independent militaries in provoking war, and of interest group capture (or the countervailing delegation of authority to strong executives) in foreign economic policy. ${ }^{33}$ In contrast to the idealist theories considered earlier, which assume that social actors are responsive to external socialization and often altruistically motivated, republican liberal theories assume that states are self-interested and rational in their pursuit of (varying) underlying national interests, which reflect in turn variation in the nature of domestic social pressures and representative institutions. ${ }^{34}$

A useful republican liberal starting point for the problem at hand is to assume that international institutional commitments, like domestic institutional commitments, are self-interested means of "locking in" particular preferred domestic policies-at home and abroad - in the face of future political uncertainty. This presumption, which is not only consistent with republican liberalism but also draws on theories widely employed to explain domestic delegation to courts and regulatory authorities in American and comparative politics, treats domestic politics as a game in which politicians compete to exercise public authority. ${ }^{35}$ Terry Moe observes that "most political institutions ... arise out of a politics of structural choice in which the winners use their temporary hold on public authority to design new structures and impose them on the polity as a whole.... [Institutions are] weapons of coercion and redistribution ... the structural means by which political winners pursue their own interests, often at the great expense of political losers." 36 Governments establish courts, administrative agencies, central banks, and other independent bodies as means by which the win-

ism-the strand of liberal theory based on the tendency to promote domestic provision of public goods (national identity, political institutions, and legitimate economic redistribution) preferred by domestic actors. (This differs from idealist theory in the minimal role it accords altruism or transnational socialization.) On the ideational strand of liberal theory, see Moravcsik 1997; and Van Evera 1990. In American or comparative politics, such an explanation might be thought of as drawing on public choice theory, institutionalist theory, constitutional theory, the theory of delegation, or theories of nested games.

33. For a discussion on the full range of potential liberal explanations, see Moravcsik 1997.

34. Liberal international relations theories assume that states behave as rational, unitary actors in the pursuit of their underlying preferences, though not in the definition of those preferences. Their theoretical distinctiveness lies in their consistent focus on variation in national preferences resulting from social pressures for particular material and ideational interests, as well as the way such interests are represented by state institutions. In this regard, institutional variants of democratic peace theory and theories of legislative-executive relations share common liberal theoretical assumptions. For an elaboration, see Moravcsik 1997; Doyle 1986; Russett 1993; Snyder 1991; Bailey, Goldstein, and Weingast 1997; Van Evera 1999; and Legro and Moravcsik 1999.

35. Moe 1990.

36. Ibid., 222, 213. In the domestic constitutional context, provisions are locked in by the fact that only a supermajority is typically able to amend it. Supermajorities bind subsequent majorities. The case we are analyzing here, like the case of administrative delegation, is more complex, since treaties are generally ratified by majority, and the nondemocratic opponents are constrained not by their majority but by the extent of their coercive power. Pasquino 1998. 
ners of political conflict seek to commit the polity to preferred policies. From this perspective, a rational decision to delegate to an independent body requires that a sitting government weigh two crosscutting considerations: restricting government discretion and reducing domestic political uncertainty.

Consider first the surrender of national discretion, which in the international context might be termed the sovereignty cost of delegation to an international authority. All other things equal, governments in power prefer to maintain short-term discretion to shape collective behavior or redistribute wealth as they see fit. They are therefore inherently skeptical of delegation to independent judges or officials, since there is always some "agency cost" to the operation of central banks, administrative agencies, courts, and other quasi-independent political authorities. Judges, in particular, may seek to negate government actions by nullifying them outright or by failing to enforce them effectively. Legal scholars William Landes and Richard Posner observe that "the outcomes of the struggle can readily be nullified by unsympathetic judges-and why should judges be sympathetic to a process that simply ratifies political power rather than expresses principle?" They point to the sixty years preceding the New Deal in the United States, during which the federal judiciary obstructed reforms favored by Congress. ${ }^{37}$

In the international realm, the defense of governmental discretion translates into the defense of national sovereignty. All other things equal, the "sovereignty cost" of delegating to an international judge is likely to be even greater than that of delegating to a domestic judge. One reason is that cross-national variation in the precise nature, scope, application, and enforcement of human rights is likely to be greater than domestic variation. Any common international list of human rights is therefore likely to diverge further from individual national traditions and practices. In the most extreme cases, for example, Great Britain, international human rights regimes introduce an explicitly enumerated bill of rights for the first time. Many international human rights regimes establish, moreover, single, centralized institutional mechanisms for interpreting, enforcing, and balancing various rights. For such bodies to develop a coherent jurisprudence, they must override local particularities. Whereas judicially imposed harmonization may seem attractive to those who draft international covenants, it clearly imposes inconvenient constraints on individual national governments. Particularly for nations without a constitutional court-again, Britain is a striking example - the procedure marks a significant innovation. ${ }^{38}$ These inconveniences may arise, moreover, not simply as a result of pressure from parochial special interests or unthinking adherence to tradition, but also through divergence in deeply rooted historical conceptions of the relationship between citizens and the state. From this perspective, the defense of "national sovereignty" is, in part, a legitimate defense of national ideals, political culture, and even democratic practices-a 
problem of which the framers of post-World War II human rights documents (and their academic advisers) were quite aware. ${ }^{39}$

Why would a national government, democratic or not, ever accept such external normative and institutional constraints on its sovereignty? The answer lies in the second major consideration that enters into a government's decision whether to delegate to an independent political body: reducing political uncertainty. In the republican liberal view, politicians delegate power to human rights regimes, such as domestic courts and administrative agencies, to constrain the behavior of future national governments. As Moe explains, a politician must always calculate that "while the right to exercise public authority happens to be theirs today, other political actors with different and perhaps opposing interests may gain that right tomorrow." 40 To limit the consequences of this eventuality, government authorities may thus seek to "lock in" favored policies in such a way, thereby insulating them from the actions of future governments.

From this perspective, human rights norms are expressions of the self-interest of democratic governments in "locking in" democratic rule through the enforcement of human rights. By placing interpretation in the hands of independent authorities managed in part by foreign governments - in other words, by alienating sovereignty to an international body - governments seek to establish reliable judicial constraints on future nondemocratic governments or on democratically elected governments that may seek (as in interwar Italy and Germany) to subvert democracy from within. In the language of international relations theory, this "two-level" commitment "ties the hands" of future governments, thereby enhancing the credibility of current domestic policies and institutions. ${ }^{41}$ Salient and symbolic international constraints serve as signals to trigger domestic, and perhaps also transnational and international, opposition to any breach of the democratic order. Thus democratic regimes seek to prevent political retrogression or "backsliding" into tyranny.

The decision of any individual government whether to support a binding international human rights enforcement regime depends, in this view, on the relative importance of these two basic factors: Sovereignty costs are weighted against establishing human rights regimes, whereas greater political stability may be weighted in favor of it. If we assume that the inconvenience governments face is constant (or randomly distributed), it follows that a country is most likely to support a human rights regime when its government is firmly committed to democratic governance but faces strong internal challenges that may threaten it in the future. Its willingness to tolerate sovereignty costs increases insofar as the costs are outweighed by the benefits of reducing domestic political uncertainty.

If the republican liberal view is correct, the strongest support for binding human rights regimes should come not from established democracies but from recently es- 
tablished and potentially unstable democracies. Only where democracy is established but nondemocratic groups (military officers, communists, fascists, and religious fundamentalists, for example) pose real threats to its future is the reduction of political uncertainty likely to outweigh the inconvenience of supranational adjudication.

It is obvious that opposition will come in part from dictatorships (or transitional regimes), since such governments both lack any interest in democracy and suffer particularly large inconveniences from persistent challenges to their (nondemocratic) domestic order. ${ }^{42}$ (Governments striving to complete a transition to democracy through extralegal means are likely to be almost as skeptical.) Less obvious and in striking contrast to realist and idealist accounts, however, is the prediction that dictatorships will be joined in opposition to binding commitments by well-established liberal democracies. By accepting binding obligations, governments in established democracies incur an increased, if modest, risk of de facto nullification of domestic laws without a corresponding increase in the expected stability of domestic democracy, since the latter is already high. Such governments have good reason-indeed, a democratically legitimate reason - to reject any reciprocal imposition of international adjudication and enforcement of human rights claims.

This is not to say that established democracies never have an incentive to support international human rights instruments. According to republican liberal theory, established democracies have an incentive to promote such arrangements for otherswhich may involve some small risk of future pressure on established democracies to deepen their commitment-in order to bolster the "democratic peace" by fostering democracy in neighboring countries. ${ }^{43}$ This is most likely to occur when democratization is expected to pacify a potentially threatening neighbor or solidify opposition to a common nondemocratic enemy. In such cases, established democracies can be expected to support rhetorical declarations in favor of human rights and regimes with optional enforcement that bind newly established democracies but exempt themselves. Yet there is little reason to believe that this concern will outweigh domestic interests; thus they are likely to remain opposed to reciprocally enforceable rules. ${ }^{44}$ Further observable implications concerning national tactics and confidential discussions are developed in the next section.

42. Governments must of course have sufficient freedom at the current time to act-a point stressed by Moe. It would therefore be somewhat surprising to see a democratic government that requires nondemocratic means to stay in power-for example, a government under heavy military influence or engaged in a civil war-take such a step. For this reason such transitional regimes-Greece in the immediate postWorld War II period or Russia today are examples_-may remain skeptical of enforceable commitments.

43. Russett 1993. This argument is liberal rather than realist, since for realists the domestic governance of states should make no difference in the perception of threat, whereas for democratic peace theorists, it does.

44. In theory, one might argue that the incomplete adherence of established democracies could be expected to undermine the international regime, which could in turn destabilize newly established democracies and thereby create threats to established democracies. Yet in practice the signaling function of international norms in any given country does not appear to depend on the adherence by others to enforcement clauses; certainly this conjecture seems to have played an unimportant role in British or European deliberations. 


\section{Testing the Theories: The Negotiation of the ECHR}

What light does the negotiating history of the ECHR cast on the power of these three competing theories? The negotiation of the ECHR took place between 1949 and 1953 under the auspices of the Council of Europe. At the first session of the Council of Europe's Consultative Assembly in September 1949, its legal committee under the chairmanship of the Frenchman Pierre-Henri Teitgen recommended that an organization be created to ensure adherence to human rights in Europe. Extended meetings of governmental committees and consultations with the assembly itself through the first half of 1950 led to the signing of the ECHR, which came into force three years later.

Realist, ideational, and liberal institutional theories all offer prima facie explanations for the general form and timing of the ECHR's establishment. For realists, this period marked the dawning of an "American century" and a moment in which the West became embroiled in a bipolar conflict with the Soviet Union. For ideational theorists, it immediately followed the Holocaust, a salient historical event of considerable moral force, and occurred immediately after the rise to salient Western leadership of two long-established democratic exemplars, the United States and the United Kingdom. ${ }^{45}$ During the immediate postwar period, republican liberals might observe, a wave of new liberal democracies emerged (or reemerged) across Western Europe. Nondemocratic institutions were widely viewed as a source of both World War II and the Cold War, and, accordingly, the democratization of Germany, Italy, and other West European nations was seen as a guarantee against both a revival of fascism and the spread of communism.

To assess the relative importance of these three plausible theories, we therefore require more fine-grained evidence than a simple coincidence of timing or the existence of occasional public rhetorical justification. I consider three types of evidence: the cross-national pattern of national positions, the process of international negotiation, and the direct documentary record of national motivations. What does the historical record reveal?

\section{Cross-National Variation in National Preferences}

We have seen that both realist and ideational theories predict that the most firmly established and committed democracies (or democratic great powers) - in short, the major Western powers led by the United States and the United Kingdom-would have been the primary supporters of binding international human rights norms. On the contrary, the historical record strongly supports the republican liberal theory, which predicts that newly established democracies will spearhead support for binding international human rights guarantees, whereas long-established democracies will support only rhetorical or optional commitments—and even these only where needed to bolster the "democratic peace." Dictatorships or governments that have not completed the transition to democracy will be opposed outright. 
We can measure the willingness of governments to accept binding obligations by examining their position on two related elements of the institutional design of the ECHR - both essential to the future effectiveness of the regime.

- Compulsory jurisdiction: Should the regime mandate that member states recognize the jurisdiction of an independent international court, as opposed to a body of foreign ministers?

- Individual petition: Should the regime mandate that member states grant private individuals and groups standing to file cases?

Since both mandatory binding jurisdiction and individual petition are required to render a system of international human rights adjudication effective, a vote for both is defined as support for a reciprocally binding regime, whereas a vote against either marks opposition. ${ }^{46}$ Positions on these two issues generated parallel (if not precisely identical) coalitions among national governments, suggesting that they tap a single underlying dimension of state preference. ${ }^{47}$

To investigate the relationship between democratic governance and support for binding regimes, we also require a measure of how stable a democracy is expected to be. ${ }^{48}$ European political systems involved in the negotiations can be divided into three categories. The first category, "established democracies," contains those systems that had been continuously under democratic rule since before 1920 and remained so thereafter: Belgium, Denmark, Luxembourg, Netherlands, Norway, Sweden, Netherlands, and the United Kingdom. (Occupation is not coded as a suspension of domestic democracy, but the establishment of a nondemocratic domestic regime is-for example, Vichy France) The second category, "new democracies," contains

46. Sikkink suggests a less satisfactory coding, one which conflates the domestic and external concerns of governments in such a way as to greatly exaggerate the relative importance of the latter. Sikkink 1993. In fact only a miniscule set of ECHR cases have been brought by one state against another.

47. Council of Europe 1975, IV/248-52, also 132ff, 242-96, also I/xxiv, 10-24, 296ff; passim, and $\mathrm{V} / 68-70$. By the time the member states negotiated individual petition, underlying positions were harder to make out, since it was becoming increasingly clear that such provisions will be optional. Austria, Belgium, France, Germany, Iceland, Ireland, and Italy supported creation of a court of human rights and mandatory jurisdiction, whereas Denmark, Greece, Luxembourg, the Netherlands, Norway, Sweden, Turkey, and the United Kingdom were opposed to anything except a court with optional jurisdiction. On the question of whether the right of individual petition should be automatic, there was slightly more ambivalence, but Britain, Greece, and perhaps also the Netherlands remained the most skeptical. On the question of the scope of the rights to be protected under the regime, a similar cleavage emerged, with advocates of a strong system, such as Teitgen, supporting an open-ended grant of institutional authority. See Council of Europe 1975, I/276. More skeptical countries, such as Britain, the Netherlands, Sweden, and Denmark, sought a more precise and narrower enumeration of rights and warned against an ambitious, open-ended system. Council of Europe 1975, I/80-82, 88-90; III/254-56, but 268.

48. Conventional political science measures of "democracy" are inappropriate, since such measures assess institutions' levels of democracy, not future expectations of democratic stability. The length of continuous democratic rule is a conventional measure in the literature on the democratic peace and elsewhere for the depth of commitment to democracy. See, for example, Russett 1993. As a more problematic check on the measure, one might also consider whether the regime remained a liberal democracy after 1950. Such ex post coding is problematic, though not entirely inappropriate, since what we seek to measure is not how democratic a state is, but how stable its democracy is perceived to be. In any case, the two measures are closely correlated. 
those that were firmly established during the negotiations and remained so thereafter, but only since a point between 1920 and 1950: Austria, France, Italy, Iceland, Ireland, and West Germany. The third category, "semidemocracies and dictatorships," contains the two governments that were not fully democratic by 1950, because of civil war or internal repression (and did not remain so thereafter), namely Greece and Turkey. Spain and Portugal, though not involved in the negotiations, also belong in this category. ${ }^{49}$

Turning to the findings, we see little evidence of the positive correlation between support for binding regimes and power or length of democratic rule predicted by realist and idealist theory. Instead, we observe the inverse-U-shaped relationship between the stability of democracy and support for binding human rights commitments predicted by republican liberal theory. Table 2 summarizes the findings. All six new democracies (plus one of the ten long-established democracies, Belgium) support binding human rights guarantees. In contrast, six of the seven established democracies join the four transitional governments and nondemocracies in opposing one or both such guarantees (or, in the case of Luxembourg, abstaining). Even the sole exception, Belgium, is not fully disconfirming, since Belgian representatives originally sided with the other established democracies against binding guarantees, shifting their position only late in the negotiations. ${ }^{50}$ The correlation is so strong that even recategorization of borderline cases-France and Turkey, say-would not undermine the striking relationship.

A number of ad hoc conjectures suggested by historians, legal academics, and common intuition about postwar European politics also fall by the wayside. Opposition appears to be uncorrelated with the possession of colonies. ${ }^{51}$ Among major colonial powers, Britain and the Netherlands are skeptics, whereas France and Belgium are supporters. Among countries without colonies, Germany and Italy are supporters, whereas the Scandinavian countries (Iceland excepted) are opponents.

Opposition is similarly uncorrelated with the existence of a strong domestic tradition of parliamentary sovereignty, as some analysts of Britain conjecture. Many strong supporters-France, Belgium, Italy, Germany, Austria, Iceland, and Ireland — shared an equally deep tradition of parliamentary sovereignty. Any imputation of causality from the correlation between postwar support for domestic judicial review and international enforcement of human rights (say, in the cases of Italy, Germany, and Austria), furthermore, is very likely to be spurious. Postwar Germany contemporaneously adopted systems of constitutional judicial review, thereby shifting political weight away from a traditionally sovereign parliament toward a separation of powers involving an independent judiciary. In Italy, Christian Democrats fearing the advent of a Socialist-Communist majority placed a constitutional court in the postwar constitution. It is far more plausible that these countries adopted both domestic and international judicial review because of a strong desire to bolster the democratic

49. For a further discussion of this coding, see the notes to Table 2 .

50. Council of Europe 1975, I/80-82, 88-90, III/254-56, but 268.

51 . This is the factor most often mentioned in the secondary literature. 
TABLE 2. Stability of democratic governance and national positions on the European Convention on Human Rights

\begin{tabular}{|c|c|c|c|}
\hline & $\begin{array}{c}\text { Unstable or } \\
\text { non-democracies } \\
\text { (stable democracy } \\
\text { not yet clearly } \\
\text { established by 1950) }\end{array}$ & $\begin{array}{c}\text { New democracies } \\
\text { (continuous } \\
\text { democracy only } \\
\text { since a date between } \\
1920 \text { and 1950) }\end{array}$ & $\begin{array}{c}\text { Established } \\
\text { democracies } \\
\text { (continuous } \\
\text { democracy since a } \\
\text { date before 1920) }\end{array}$ \\
\hline $\begin{array}{l}\text { Supports enforcement } \\
\text { (individual petition } \\
\text { and compulsory juris- } \\
\text { diction mandatory) }\end{array}$ & - & $\begin{array}{c}\text { Austria, France, Italy, } \\
\text { Iceland, Ireland, } \\
\text { Germany }^{\mathrm{b}}\end{array}$ & Belgium $^{c}$ \\
\hline $\begin{array}{l}\text { Opposes enforcement } \\
\text { (individual petition } \\
\text { and/or compulsory } \\
\text { jurisdiction optional } \\
\text { or absent) }\end{array}$ & $\begin{array}{c}\text { Greece, }{ }^{\mathrm{a}} \text { Turkeya } \\
\text { (Portugal, }^{\mathrm{d}} \text { Spain }^{\mathrm{d}} \text { ) }\end{array}$ & - & $\begin{array}{c}\text { Denmark, Sweden, } \\
\text { Netherlands, Norway, } \\
\text { United Kingdom, Lux- } \\
\text { embourg }^{\text {e }}\end{array}$ \\
\hline
\end{tabular}

${ }^{\mathrm{a}}$ Greece and Turkey are characterized as unstable, whereas Austria, France, Italy, Iceland, Ireland, and Germany are characterized as new, because (1) it had been less than a year after conclusion of the bloody Greek civil war, and extra-legal measures were still in force; and (2) Greek and Turkish democracy were widely viewed as limited by the role of the military and incomplete judicial autonomy. It is also worth noting that both governments would subsequently slip back into dictatorship. This coding is consistent with the general literature on delegation, which notes that governments must have sufficient power to put institutions in place. Governments unable to rule by established democratic means belong in the nondemocratic category.

${ }^{\mathrm{b}}$ Germany, not yet a member of the Council of Europe, did not have voting rights, but participated actively in the negotiations.

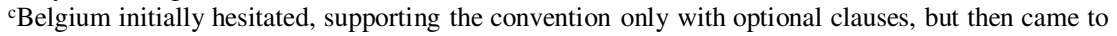
favor mandatory enforcement.

${ }^{\mathrm{d}}$ Spain and Portugal, both dictatorships, were not members of the Council of Europe. Yet, in striking contrast to Germany (also not a member), they showed little independent interest in participating informally, nor were they invited to do so.

'In some cases, Luxembourg abstained on, rather than opposed, enforcement measures.

order, not that the inclusion of a constitutional court in the postwar constitution had immediate implications for the national position on the ECHR. ${ }^{52}$ In sum, the establishment of domestic constitutional review, like the establishment of international human rights guarantees, is a postauthoritarian phenomenon. National positions are uncorrelated with support for European federalism: the Netherlands and Luxembourg opposed mandatory enforcement, whereas Austria, Ireland, and Iceland favored it. More consistent with the republican liberal view is the conjecture that both support for Europe (in this very early period, this meant support for the Council of Europe and the European Coal and Steel Community) and support for a binding ECHR reflect (in this period but not later) the influence of a third factor-say, demo- 
cratic stability and security threats. ${ }^{53}$ Finally, the experience of being invaded by Germany during World War II seems to explain little. The French and Belgians favored mandatory enforcement, whereas the Dutch, Danes, and Norwegians opposed it.

Republican liberal theory also seems to offer the most accurate account of the instrumental attitude governments adopted toward more detailed provisions of the ECHR. Should the convention create, governments asked themselves, an independent court, a quasi-judicial body of government representatives, or no central institution at all? Cleavages around this issue were similar to those around compulsory jurisdiction and individual petition, with opponents of effective enforcement opposing the court. ${ }^{54}$ Governments favorable to binding human rights adjudication proposed that the members of the intermediary Commission on Human Rights be nominated by the court - a clear effort to render international institutions more independent-whereas more skeptical governments favored granting power of nomination to the intergovernmental Committee of Ministers. ${ }^{55}$

Similar cleavages formed around the enumeration of rights. Some skeptics considered delaying the proceedings, as well as limiting future uncertainty, by pressing for a precise enumeration of rights or transferring the issue to the less-effective UN Commission on Human Rights. ${ }^{56}$ In the end, the precise enumeration of rights, which was considerably narrower than that granted by any member state with such a constitutional enumeration, resulted from a careful calculation of instrumental, selfregarding considerations. ${ }^{57}$ Representatives of right- and left-wing parties were concerned about the status of particular laws favored by their constituencies. Social Democratic representatives assured that social welfare rights were not threatened and that property rights did not restrict state intervention. Christian Democratic representatives assured that rights of private familial, educational, and religious choice were maintained, while opposing any right to redistribution of property..$^{58}$ The final docu-

53. See Glendon 1998a, 1170-72. See also Slaughter, Stone Sweet, and Weiler 1998.

54. Council of Europe 1975, IV/248-50.

55. Council of Europe 1975, III/268-70.

56. Council of Europe 1975, III/268, 304, 306, IV/178, also 106-108.

57. For the most plausible argument for the impact of the UN Declaration, see Teitgen 1988, 481, 490. The enumeration of rights also did not simply conform to a focal point established a few years before in the UN Declaration-the sort of transnational dynamic of standard-setting many ideational theorists stress. Despite similarities in wording, advocates saw the European system in this respect not simply as a continuation of the UN system, but also as a pragmatic reaction to it. The UN system was widely viewed as too broad to be effective; the ECHR system was designed to be potentially enforceable, which required that the scope of rights be narrowed considerably. Indeed, the principal author of the UN Declaration, the Frenchman Réne Cassin, overtly opposed the creation of the ECHR. Finally, even the enumeration of rights in the UN Declaration was drawn not from proposals of activists per se, but primarily from systematic and scholarly analyses of comparative law (such as from the American Law Institute and UN officials) as well as international documents (such as the Pan American Declaration), then whittled down through intergovernmental negotiation. Glendon 1998a; Glendon 1998b, chap. 3; Humphrey 1984, 31-32; Teitgen 1988, 489-92; and Morsink 1999.

58. For reports of debates on marriage, education, and property, see Council of Europe 1975, I/166-86, 242-64; II/48-132. For a response to the possible objection that these rights were controversial because they are intrinsically more difficult to define, see ibid., V/304-14. 
ment offended neither side, because it was constrained to include only the least controversial among basic political and civil rights. ${ }^{59}$

\section{The Domestic and International Decision-making Process}

Realism, ideational theory, and republican liberalism also generate distinctive predictions about the tactics likely to be most salient in interstate negotiations. Realist theory, with its stress on interstate power and deep conflicts of interest, leads us to expect to observe attempts by great powers to coerce or bribe weaker states to change their policies. Ideational theory, by contrast, leads us to expect to observe attempts by governments or transnational groups in civil society to engage in transnational persuasion. Such persuasion may suffice in itself or may be a prelude to subsequent coercive tactics. For liberal theorists, by contrast, there is little reason to expect governments to alter their views on fundamental issues such as the nature of constitutional adjudication in light of threats, promises, or normative persuasion by other democratic governments. The interest of established democracies in the stability of neighboring, less-established democracies is surely less intense than the domestic self-interest of new democracies; hence established democracies cannot easily be induced to accept domestic constraints in order to make the regime work-particularly when the option of creating optional enforcement mechanisms exists. ${ }^{60}$

Published documents contain very little direct confirmation of either the realist or ideational predictions. No great power or long-standing democracy appears to have made threats or offered inducements to secure stronger commitments. The most important powers engaged in Western Europe at the time, the United States and the United Kingdom, were respectively absent or opposed. Ideational theorists might point out that the "European Movement," working through the Assembly of the Council of Europe, was engaged in transnational discussion and mobilization. Certainly many leading advocates of the convention were European federalists and viewed the ECHR as a step toward European integration. ${ }^{61}$ Yet there is little evidence that a shared transnational discourse influenced the positions of parliamentary politicians in the assembly, let alone representatives of national governments. There is, we have seen, little correlation between national positions on the ECHR and positions on European integration. Indeed, we observe little shift in national positions at all, let alone influence wielded by established democracies, as predicted by ideational theory. Although we cannot entirely exclude the possibility that subtle forces of transnational persuasion and mobilization played a modest role in organizing the forum for discussion, they were surely not decisive in defining the positions of the participating governments.

\section{Teitgen 1988, 480 .}

60. Liberal theory predicts that interstate bargaining outcomes are a function of the relative intensity of national preferences. Governments that strongly seek a particular cooperative outcome will concede more in order to achieve it. Moravcsik 1997.

61. Some Jewish parliamentarians and law professors were also prominent and may have been influenced by their experiences and beliefs. 
Instead the preponderance of evidence concerning negotiating tactics confirms republican liberal predictions. Rather than seeking to coerce or persuade one another, or mobilizing groups in civil society, national governments conducted a classical international negotiation. Governments focused primarily on practical compromises that would assure that the system functioned to assure each state its preferred level of sovereign control. New institutions were modified to a compromise close to the lowest common denominator, with no government forced to accept immediate constraints on its own policies significantly greater than those it ideally sought. Where there was discord, optional clauses afforded governments flexibility. The real explanation of the outcome, as liberal theory predicts, lies in the pattern of underlying national preferences.

\section{Domestic Deliberation and Public Justification}

The final type of evidence consists of the records of confidential deliberations and public justifications by national decision-makers, drawn from debates in the Parliamentary Assembly of the Council of Europe, negotiating sessions among the national governments, and the documentary record of confidential deliberations in one critical country where such documents are available, namely the United Kingdom. What do these reveal?

Let us begin by noting a salient fact. Not a single piece of documentary evidence in the sources I have been able to consult supports the realist prediction that governments impose international human rights norms through threats of external coercion or inducement. At no point do we observe governments weighing the costs and benefits of coercion, concerning themselves with the distribution of power capabilities, or mentioning foreign or military aid.

There is slightly more evidence for the ideational view, but not enough to establish any confidence in its veracity. At most, NGOs and public opinion appear to have played a secondary, even insignificant, role. ${ }^{62}$ The rhetoric of politicians in the European Assembly, as well as some interest groups, invoked moral considerations. Yet for the ideational theory to be confirmed, such statements must be designed to socialize or persuade national governments by appealing to respect for human rights as an end in itself, rather than as an instrument to promote concrete ends of enduring interest to member governments - the prevention of tyranny, genocide, and aggression. There is no evidence of this; positions, as we have seen, do not change. In Britain, we observe officials in occasional meetings with NGOs. A 1951 Colonial Office draft circular blandly recalled "in deciding to sign the Convention, His Majesty's Government took into account the importance attached to it by public opinion both in and outside this country." ${ }^{63}$ Yet, although NGOs were relatively well developed in Britain (perhaps more so than anywhere else) and made salient contributions

62. For a similar conclusion regarding the abolition of the slave trade, see Kaufman and Pape 1999.

63. Marston 1993, 824. Some British officials attributed the support of other governments for a human rights court to their desire to assert the symbolic significance of the council vis-à-vis the claims of Communist governments and parties. Marston 1993, 809. 
to the specific form of the final document, the British government paid little heed to their pleas to accept mandatory enforcement. The issue was neither debated in Parliament nor mentioned in election campaigns. British public opinion, like public opinion elsewhere, took relatively little note of the ECHR negotiations.

The overwhelming bulk of the documentary evidence confirms instead the republican liberal account. By far the most consistent public justification for the ECHR, to judge from debates in the Council of Europe Constituent Assembly, was that it might help combat domestic threats from the totalitarian right and left, thereby stabilizing domestic democracy and preventing international aggression. (It is helpful to remember that both Hitler and Mussolini came to power, at least initially, by constitutional means.) Teitgen, the chief French advocate of the ECHR in the assembly, considered "Fascism, Hitlerism, and Communism" as the major postwar threats to democracy. ${ }^{64}$ Governments, Teitgen argued, should seek to "prevent—before it is too late—any new member who might be threatened by a rebirth of totalitarianism from succumbing to the influence of evil, as has already happened in conditions of general apathy. It is not enough to possess freedom; positive action must be taken to defend it. . . Would Fascism have triumphed in Italy if, after the assassination of Matteoti, this crime had been subjected to an international trial?" ${ }^{5}$ Yet postwar human rights regimes were a response not simply to the recent fascist past but also to the prospect of a Communist future. The latter was mentioned just as often. In this period, we must recall, the French Communist Party enjoyed plurality electoral support. Teitgen spoke of the "abominable temptation" to "exchange . . f freedom for a little more bread."

Such concerns were linked explicitly to the shared belief that nondemocratic states tend toward international aggression as well as domestic oppression. Teitgen's motivation was, at least in part, to assure the stability of German democracy and thereby the security of France. None other than Konrad Adenauer told Teitgen in 1949 that integration was needed to restrain postwar Germany, not just the Soviet Union. Teitgen reports he "needed no more" to convince him to work for the Council of Europe. ${ }^{67}$ Such arguments were advanced by the ECHR's advocates in the assembly far more often than any others. This clearly refutes the conjecture-which, as we have seen, Sikkink and Keck treat as an essential piece of evidence for ideational theorythat few analysts before the 1980s could possibly have been aware of a link between democracy and peace. In many ways the democratic peace proposition, which dates from the eighteenth century, was a central tenet, arguably the central tenet, of postwar Western planning, as it had been in the thinking of Woodrow Wilson and other liberal statesmen a generation before. ${ }^{68}$

Yet domestic self-interest dominated. The most explicit justifications for the ECHR as a bulwark against future tyranny were advanced not by representatives from coun-

64. Council of Europe 1975, I/40-42.

65. Council of Europe 1975, I/192, 120, 64, also 60-64, for statements by others, I/66, 84, 120ff, 192-94, 276, 278-80, 292.

66. Council of Europe 1975, I/40-42.

67. Teitgen $1988,476$.

68. Keck and Sikkink 1998, 203. Compare footnote 27. See Moravcsik 1992 and 1997. 
tries with the longest democratic heritage but, as republican liberal theory predicts, by those from newly established democracies. Among the most persistent advocates of this position were Italian and German representatives. (Germany was not a formal member of the Council of Europe but enthusiastically sought to participate, in striking contrast to the disinterest shown by Spain and Portugal.) The Italian representative to the assembly who advanced perhaps the most extensive proposal for centralized institutions, one Mr. Benvenuti, stressed the need to prevent totalitarian movements-a problem, he argued, particularly important in nations where democracy is not yet firmly established. Another Italian representative affirmed "the principle of the joint responsibility of democratic states." ${ }^{69}$ A German representative went further, proposing a treaty obliging all member states to come to each other's aid, apparently with force, if domestic freedom were threatened. ${ }^{70}$

Yet the primary expectation was not that the regime would strengthen democracy by mobilizing intervention by foreign governments to enforce human rights norms, as realist and some ideational theory might lead us to expect. Nor did governments stress active transnational mobilization. Most participants appear to have felt that domestic politics would remain the primary site of enforcement-all members were to be democracies, at least formally - with international controls serving as an external signaling device to trigger an appropriate domestic response. ${ }^{71}$ The ECHR was intended primarily to strengthen existing domestic institutions of judicial review, parliamentary legislation, and public action, not to supplant them. Even skeptical British officials voiced little fear of direct foreign intervention on domestic politics, fearing instead the mobilization of domestic groups.

Critics in the assembly often asked why an arrangement was required at all, if its scope was restricted to existing democracies. Nowhere was republican liberal logic clearer than in the responses given by advocates. The arrangement was primarily a means to prevent backsliding by new democracies. As Sir David Maxwell-Fyfe of the United Kingdom put it: "In answer to the criticism that, as signatories will be limited to democratic states the Convention is unnecessary ... our plan has the advantage of being immediately practicable; it provides a system of collective security against tyranny and oppression." 72

Unlike the UN system, the ECHR was designed to be enforceable-a goal, Maxwell-Fyfe argued, that was realistic only because all of its members already shared an essentially democratic political culture. ${ }^{73}$ Among skeptics, the primary focus of criticism was, as republican liberal theory predicts, the fear that the application of domestically legitimate national laws might be declared in violation of the convention. The compatibility of the ECHR with existing domestic legal practices dominated discussion-a fact suggesting also that decision-makers took the commitment seriously. ${ }^{74}$ 
On this point it is instructive to examine more closely the contrary position of one government, namely that of the United Kingdom. From a methodological perspective the United Kingdom is a critical case. Opposition by the oldest and most firmly established democracy in Europe constitutes a particularly striking disconfirmation of realist and ideational theory. ${ }^{75}$ The British, as we have seen, supported international declaratory norms but firmly opposed any attempt to establish binding legal obligations, centralized institutions, individual petition, or compulsory jurisdiction. ${ }^{76}$ As W. E. Beckett, legal advisor to the Foreign Office and the initiator of the British government's participation, put it, "We attach the greatest importance to a welldrafted Convention of Human Rights but we are dead against anything like an international court to which individuals who think they are aggrieved in this way could go." 77 Even Beckett conceded the existence of "overwhelming objections" to any strong means of enforcement in Britain involving the individual right of petition and an independent tribunal-despite his efforts to work with British NGOs on specific proposals.

What issues were raised in confidential British deliberations? The secondary literature on British human rights policy makes much of two British concerns: the fear that residents of British colonies and dependencies might invoke the ECHR, and aversion to European federalism. To judge from confidential discussions, however, neither appears to have been a dominant concern. To be sure, Colonial Secretary Jim Griffiths was concerned that "extremist politicians" among "politically immature" colonies would exploit the document. ${ }^{78}$ Yet overall there is surprisingly little discussion of colonial implications in the deliberations - certainly far less than purely of domestic considerations. Colonial Office concerns appear to have been isolated and intermittent. In any case, a colonial clause in the ECHR would limit any such claims, and consideration of such a clause did not blunt British opposition. ${ }^{79}$ Nor, despite the fact that the Council of Europe Assembly was the locus of European federalist activity, do British government officials often mention the connection between human rights and European federalism. The British government resisted efforts to make international human rights law directly enforceable in this way, regardless of whether its forum was European or not-and continued to do so for some time thereafter. ${ }^{80}$

Confidential domestic deliberations suggest instead that British opposition reflected what A. Maxwell, permanent secretary to the Home Office, described as "grave apprehension about what might happen at home." 81 When the issue finally reached the Cabinet, the attention of ministers - after brief mention of colonial and economic

75. The UK position was also viewed as decisive. See, for example, Paul-Henri Spaak, cited in Teitgen 1988 , 478. Britain is also a country for which we have a wealth of reliable archival documents and oral histories. I have restricted myself here to materials found in published sources.

76. Marston 1993, 799-800.

77. Marston 1993, 804.

78. Lester 1984, 50. See also Lester 1994, 2; and Marston 1993, 812.

79. Marston 1993, 806-807, 809-10, 812, 816. In 1953 the British government voluntarily extended the Convention to the forty-two overseas territories for whose international relations they were responsible.

80. See Lester 1984, 55; and Lester 1994, 3.

81. Marston 1993, 813. 
concerns-seems to have focused on domestic application. Precisely as republican liberal theory predicts, the primary concern was not the vulnerability of the overall British record on human rights. As Parliamentary Secretary for Foreign Affairs Hector McNeil observed in a 1947 memo to Prime Minister Clement Atlee, Britain had an "extremely good record." British decision-makers appear sincerely to have believed that Britain would be less inconvenienced by reciprocal commitment than other member governments. The definition of rights in the convention was, so the Foreign Office memo to the Cabinet in 1950 concluded, "consistent with our existing law in all but a small number of comparatively trivial cases." 82

Nor did ministerial apprehension result from major public policy considerations. Most such concerns-such as the belief of some in the Labour Party, led by Chancellor of the Exchequer Sir Stafford Cripps, that the convention might restrict government intervention in the economy, including entry of government inspectors into private homes-were shared with similar political groups in other countries and were therefore handled effectively by narrowing and qualifying the explicit rights enumerated in the convention to exclude constraints on economic policy, education, and political institutions..$^{83}$

Instead British officials and politicians-most notably in Cabinet discussionsdwelled primarily on the fear that the convention would threaten idiosyncratic (but not unambiguously undemocratic) political practices and institutions in the United Kingdom. ${ }^{84}$ Yet when pressed in confidential discussions to make their concerns explicit, the examples cited by British opponents seem either absurdly vague or comically trivial.

The defense of British institutional idiosyncrasy elicited the most violent rhetoric from British politicians and officials. Lord Chancellor Jowitt's official paper criticized the draft convention, largely the work of two distinguished former British officials, as

so vague and woolly that it may mean almost anything. Our unhappy legal experts ... have had to take their share in drawing up a code compared to which ... the Ten Commandments . . . are comparatively insignificant. . . . It completely passes the wit of man to guess what results would be arrived at by a tribunal composed of elected persons who need not even be lawyers, drawn from various European states possessing completely different systems of law, and whose deliberations take place behind closed doors. ... Any student of our legal institutions must recoil from this document with a feeling of horror. ${ }^{85}$

A common complaint was that judicial review would undermine parliamentary sovereignty. Beckett wrote: "It seems inconceivable that any Government, when

82. Marston 1993, 811. With a lack of modesty about their domestic political institutions characteristic of this period, British officials and politicians also sometimes cited the need to set a good example for foreign countries as a reason for Britain to take an active role in the negotiations.

83. See Lester 1984, 50-52; and Lester 1994, 2. The British position did not change under the subsequent Conservative government of Anthony Eden.

84. Lester 1984, 54-55.

85. Ibid., 52. 
faced with the realities of this proposal, would take the risk of entrusting these unprecedented powers to an international court, legislative powers which Parliament would never agree to entrust to the courts of this country which are known and which command the confidence and admiration of the world." 86 "Our whole constitution," a government document intoned, "is based on the principle that it is for the Parliament to enact the laws and for the judges to interpret the laws." 87 The British government even opposed a clause protecting rights to "free elections" and "political opposition," apparently because they believed that their distinctive "first past the post" unique electoral system might be challenged. ${ }^{88}$

The specific issue cited most often by the government's legal authorities was the British policy toward political extremists. A ministerial brief referred to a "blank cheque" that would "allow the Governments to become the object of such potentially vague charges by individuals as to invite Communists, crooks, and cranks of every type to bring actions." ${ }^{89}$ Lord Chancellor Jowitt's complaint was that "the Convention would prevent a future British government from detaining people without trial during a period of emergency ... or judges sending litigants to prison for throwing eggs at them; or the Home Secretary from banning Communist or Fascist demonstrations." 90

Yet it would be misleading to argue that British institutional idiosyncrasy caused British opposition. Every established democracy, after all, has its treasured idiosyncrasies, and British leaders sincerely believed that, as the cradle of rule-of-law governance, they would suffer least. ${ }^{11}$ In comparative perspective, many general concernsgovernment intervention in the economy, the challenge to colonial rule, concern about political extremism, skepticism of courts, a tradition of insular nationalism, and parliamentary sovereignty - hardly distinguished Britain from France, Italy, and many other continental supporters of the convention. Many of these fears-including those concerning colonies and electoral rules - could have been and were addressed by restricting the document..$^{92}$ For British decision-makers, the decisive point was not the nature of these concrete objections but the utter absence in the British domestic context of any countervailing self-interested argument in favor of membership.

The quaint scenarios of extremist threats raised by British officials demonstrate this. They arose not because extremist groups in Britain were particularly strong but because, in comparison with the Continent, they were so weak. Whereas French, German, and Italian officials viewed the ECHR as a check on the potential triumph of

86. Ibid., 803.

87. Ibid., 799.

88. Council of Europe 1975, III/182, 264.

89. Marston 1993, 806.

90. Lester 1994, 2.

91. It is possible they were wrong. One intriguing conjecture is that the longer a democratic form of government is in place, the more attached to its idiosyncrasies citizens and elites are likely to grow, and the further from the norm of international constitutionalism its practices are likely to become. Hence we would expect countries such as Britain, the Netherlands, Sweden, and the United States to become particularly attached to their idiosyncratic national systems. If correct, this would mean that established democracies not only reap fewer benefits from international human rights enforcement but also bear greater costs.

92. Samnøy 1993, 46-47. 
popular extremist parties, British officials saw it only as a hindrance to a defense of the political system against agitation by isolated individuals. British internal debates and external statements were utterly devoid of any recognition of the advantages of collective security against domestic extremists-advantages central to continental arguments for the ECHR. Whereas the French were concerned that the Communist Party might take power electorally and have to be checked by the ECHR, the British were concerned that isolated radicals might file suit under the ECHR. In this context, marginal inconveniences overridden elsewhere in the interest of bolstering democratic stability became fundamental obstacles to the acceptance of binding international human rights norms.

For these reasons, the British government long considered opposing the convention altogether. Yet, in the words of an internal Foreign Office paper, "The alternative, namely refusal to become a party to a Convention acceptable to nearly all the remaining States of the Council of Europe, would appear to be almost indefensible. ... Political considerations, both domestic and foreign, compel us now to bring ourselves to accept" an (optional) right of individual petition. ${ }^{93}$ What blunted British opposition to any postwar European human rights regime was, above all, the fear of resurgent totalitarianism abroad that might pose an eventual military threat to the United Kingdom-precisely as republican liberal theory predicts. ${ }^{94}$ This fear reflected not just a concern with a resurgence of Fascism, but also a turnaround in British foreign policy in 1948 in response to the perceived rise of the Communist threat in Western Europe. The West, the government argued, needed not only to maintain the military balance but also to strengthen continental democracies. For these purposes, the propaganda battle against Communism was critical. Such concerns had led Britain and France to help form the Council of Europe a few years earlier. ${ }^{95}$

In the minds of British officials, however, the primacy of domestic sovereignty over collective defense of the democratic peace remained unchallenged. The cabinet mandated efforts to water down the force of any agreement in Britain. British representatives sought to limit the potential risk of open-ended jurisprudence by calling for the careful enumeration and definition of human rights before agreeing on any enforcement mechanism. The expectation was that governments would not be able to agree on a list both extensive and precise. ${ }^{96}$ Acting on Prime Minister Clement Atlee's direct instruction, the British delegation successfully pressed to place the right of individual petition and the jurisdiction of the court into optional clauses. ${ }^{97}$ Foreign Minister Ernest Bevin himself instructed British negotiators to veto any mandatory right of individual petition "even if it [means] being in a minority of one." 98 With

93. W. E. Beckett, Legal Advisor to the Foreign Office, April 1947 Foreign Office meeting, cited in Marston 1993, 798, 811, also 798-804.

94. Note that this differs from the realist account in that the threat is not, in the first instance, a function of military power, but of political and ideological difference.

95. Simpson 1998, 15-19, 37-38.

96. Marston 1993, 808. See also Council of Europe 1975, III, especially 182, 280, 304.

97. Marston 1993.

98. Marston 1993, 814. Britain withdrew its similar intention to veto over the issue of colonial dependencies. 
Cabinet approval, Britain pursued a similar policy with respect to the negotiation of UN human rights commitments. ${ }^{99}$

Having secured these concessions, which essentially rendered the convention unenforceable in Britain, the cabinet unanimously accepted the desirability of signing it. Ratification proceeded without difficulty. Subsequently, the Atlee government treated the ECHR as a declaratory document and made no effort to introduce implementing or incorporating legislation. Yet even this outcome-one with no immediate concrete consequence-was viewed among British leaders as second best. They were fully aware that once the document was signed, future domestic political pressure might well arise to incorporate the treaty or to accept its optional clauses. Foreseeing that a future government, as the lord chancellor put it, "might be forced to concede" the jurisdiction of the court, the British government sought also to include a provision permitting any state to withdraw from the ECHR on six months' notice. ${ }^{100}$

To judge from their voting record and their contributions to the assembly debatesgiven the absence, for the moment, of more detailed documentary research-the attitude of British politicians appears typical of attitudes in other recalcitrant countries, such as Sweden, Norway, Denmark, the Netherlands, and Luxembourg. Governments and publics in these countries appear to have been, on balance, more firmly committed to democracy, more altruistically inclined, and sometimes even (subsequent experience within the regime suggests) more willing to use coercion to spread human rights norms than the governments and publics of countries that favored binding commitments. ${ }^{101}$ Yet, given the high level of certainty about the future political stability of these democratic systems and the immediate benefits of sovereignty for ruling parties and government officials, there was little self-interested reason to accept compulsory and enforceable international commitments in the area of human rights. Accordingly they refused to do so.

\section{Generalizing the Argument: Human Rights and Beyond}

We have seen that the origins of the ECHR, the most successful international human rights adjudication and enforcement regime in the world today, lies not in coercive power politics or socialization to idealistic norms, as contemporary international relations theories predict. Instead its origins lie in self-interested efforts by newly

99. Foreign Secretary Herbert Morrison, in his 1951 memorandum to the cabinet on the UN Covenant, wrote, "As the United Kingdom government has always played a leading part in promoting [human rights in the UN], it would be difficult to draw back at this stage. In these circumstances, the prudent course might be to prolong the international discussions, to raise legal and practical difficulties, and to delay the conclusion of the Covenant for as long as possible.', Lester 1984, 55.

100. Lester 1984, 53-54. See also Marston 1993, 824-26. This clearly disconfirms the conjecture that future evolution was an entirely unforeseen, path-dependent consequence of earlier commitments.

101. On the subsequent willingness of Sweden, Norway, Denmark, and the Netherlands, as well as France and Austria, to pressure foreign states, see Sikkink 1993. On Sweden, see Council of Europe 1975, III/262, 264. 
established (or reestablished) democracies to employ international commitments to consolidate democracy— "locking in" the domestic political status quo against their nondemocratic opponents. This empirical finding has three broader implications for future research on domestic politics and international relations.

\section{The Origin and Evolution of Human Rights Regimes}

The first implication of the theoretical argument is that the tendency of states to enhance the credibility of domestic policies by binding themselves to international institutions may help explain the origins and evolution of human rights enforcement regimes more generally. In negotiations to create the Inter-American Convention on Human Rights, the UN Covenants, and the emergent African human rights system, we should expect to see a similar pattern of support from new democracies, suspicion from established democracies, and hostility from dictatorships. ${ }^{102}$ In the following overview I highlight suggestive evidence and propose areas for future research.

The negotiation of the UN Covenant on Civil and Political Rights appears to illustrate the dynamics of democratic commitment. At the height of the Cold War, in the early 1950s, the most stable among modern democracies, including the United States and the United Kingdom, allied with authoritarian and totalitarian states like the Soviet Union, China, South Africa, and Iran, in opposition to the inclusion of compulsory, enforceable commitments. The alliance in favor of such commitments, as republican liberal theory predicts, included recently established democracies in continental Europe, Latin America, and Asia.

Republican liberal theory also explains a troubling anomaly for scholars and activists alike, namely, the consistent unwillingness of the United States to accept multilateral constraints on its domestic human rights practices under the Inter-American and UN systems. This unwillingness is generally attributed to ad hoc, idiosyncratic factors: the United States' superpower status (as is often said of its opposition to binding UN obligations), its uniquely segregated southern states (as is often said of support for the Bricker Amendment in the early 1950s), or its unique political institutions (federalism and supermajoritarian treaty ratification rules). From the republican liberal perspective, in contrast, U.S. skepticism is the norm, not the exception, among established democracies-a norm related to the relatively low level of offsetting domestic benefits in an established, self-confident democracy, not the nature of American objections per se. ${ }^{103}$

The positions of the established democracies in recent years concerning the creation of war crimes tribunals offer at least partial confirmation of republican liberal

102. For an overview, see Robertson and Merrills 1996.

103. An intriguing parallel example is the recent refusal of the European Community's European Court of Justice (ECJ) to permit the EU to adhere collectively to the ECHR without a treaty amendment, noting that (1) there is no express human rights commitment in the Treaty of Rome, hence no legal justification for adherence, and (2) human rights already "form an integral part of the general principles of law whose observance the [ECJ] ensures.' See ECJ, I-1789. Adherence would, of course, undermine the ECJ's own authority in this area. 
theory. Established democracies had little difficulty accepting tribunals with jurisdiction over the former Yugoslavia and Rwanda, where their own policies would not be implicated. Yet where commitments were (de facto) reciprocally binding-namely, in open-ended institutional commitments involving countries that actually engage in foreign intervention-established democracies, confident that they maintain adequate domestic safeguards against domestic atrocities, hesitated to accept international constraints. In the recent International Criminal Court negotiations, three established democracies with a recent history of intervention abroad (the United States, France, and Israel) posed the greatest difficulties. After fighting to dilute the obligations of the treaty, the United States and Israel joined China and highly repressive Middle Eastern and North African states in opposition, while France was the very last major power to lend its support to the treaty. ${ }^{104}$

What about the development of human rights regimes over time? An understanding of major human rights regimes does not end with their founding. We have seen that the ECHR, like other major human rights instruments, created a number of optional clauses on individual petition and compulsory jurisdiction of the court. In some cases, early opponents of an enforceable convention remained exceptionally recalcitrant. ${ }^{105}$ Yet over the subsequent five decades, all West European governments progressively adopted such clauses and in many cases incorporated the ECHR into domestic law.

Much of this accords with republican liberal theory. We observe a strengthening of commitments during and immediately after "democratic waves"- as hit Latin America and Central Europe during the 1990s. Such efforts are strongly favored by new democracies. ${ }^{106}$ In Europe, the most important reform in the history of the ECHR, for example, was launched in the early to mid-1990s. "Protocol 11," opened for signature in May 1994, permits the ECHR Court to assume the functions of the commission and compels all new signatories to accept compulsory jurisdiction and individual petition - practices already universal among the original members. Leading legal academics argue that the most important impetus for Protocol 11 was "the widening ... to include [states] that have had little domestic, much less international, experience in the legal protection of human rights." ${ }^{107}$ The first three countries to ratify Protocol 11 were three transitional democracies: Bulgaria, Slovakia, and Slovenia. The governments of some new democracies in Central and East Europe were similarly quick to accept minority rights obligations as a means of locking in domes-

104. For a general treatment of war crimes tribunals demonstrating the unwillingness of established democracies to pay high costs, see Bass 1999.

105. Sweden and the Netherlands are among the handful of countries that have been specifically ordered by the ECHR to allow more effective domestic judicial review of human rights claims; many have argued that Britain should be on the list as well. Lester 1994.

106. Huntington 1991. Consider, however, former British colonies, which on gaining independence adopted explicit bills of rights and constitutional review-some on their own, some with the encouragement of the British government. Many were patterned after the European Convention, but the underlying impetus stems, republican liberal theory argues, from their status as emerging postauthoritarian democracies. Some of the most stable of these, such as those in the Caribbean, rejected international obligations.

107. Janis, Kay, and Bradley 1995, 88-89, 113-18. 
tic democracy. ${ }^{108}$ In the Americas, acceptance of compulsory jurisdiction by the InterAmerican Court has occurred over the past two decades - a period in which domestic constitutional review also became nearly universal. In contrast, human rights norms remain weak in those regions where new democracies are few, as in Africa or the Middle East.

Despite these important insights, however, the determinants of the evolution of human rights regimes are unlikely to be identical to the determinants of their founding and are therefore unlikely to be explained entirely by republican liberal theory. The ECHR deepened over a period during which European governments grew more confident about the stability of domestic democratic governance. Hence the theory advanced here cannot be the sole, or even the major, explanation for the subsequent deepening of the regime. A social process intervenes between original intent and ultimate evolution - a process, we have seen, of which governments were quite aware in 1950. British officials believed that the ECHR would alter domestic political arrangements so as to encourage the mobilization of new social demands for human rights enforcement. Republican liberal theory would suggest that such new demands reflect new opportunities for representation of social interests once a nation joins a regime; broader liberal theory would stress changes in social ideas and interests. Further research is required to clarify the precise dynamics of such long-term trends. ${ }^{109}$

\section{Generalizing the Theory to Other Issue Areas}

A second direction for future research is to extend the theory to cooperation in other issue-areas. Despite the "republican liberal" label, the theoretical distinctiveness of the explanation advanced here is only incidentally connected to the liberal content of the philosophy embodied in human rights regimes. In other words, the argument is theoretically rather than substantively liberal. ${ }^{110}$ Distinct to republican liberal theory is the decisive role of domestic political representation in world politics and, by extension, the possibility that international institutions, like their domestic counterparts, can enhance the credibility of domestic political commitments, thereby "locking in" current policies. Whether or not governments are "liberal," international institutions may "strengthen the state" domestically by expanding its domestic control over initiative, information, ideas, and institutions. ${ }^{111}$ Compared with more conventional "functional" theories of international regimes, which stress reciprocal commitments to manage transnational societal transactions, this analysis points to a more purely domestic or "two-level" motivation for establishing international institutions. ${ }^{112}$

Under what general conditions should we expect to observe international commitments of this kind? Republican liberal theory suggests three conditions: (1) govern- 
ments fear future domestic political uncertainty, (2) the position of the national government is supported by a consensus of foreign governments, and (3) international cooperation helps induce domestic actors to support the maintenance of current policies.

Where else in world politics might these three conditions be met? Two types of examples must suffice. Where nondemocratic governments cooperate to enhance their domestic credibility, a mirror image of human rights institutions may arise. Stephen David argues that "weak and illegitimate" leaders of developing countries often view internal enemies as more dangerous than external ones and are therefore likely to select international alliances that undermine domestic opponents. ${ }^{113}$ The Holy Alliance is a nineteenth-century example of international cooperation designed to block the seemingly inevitable spread of domestic liberalism and nationalisminside and outside its membership. A century later, ruling Communist governments in Eastern Europe, fearing for their domestic legitimacy, supported membership in the Warsaw Pact; their comrades worldwide cooperated through Comintern.

Further examples of efforts to use international regimes to bolster domestic policy credibility are found in international trade and monetary policy. ${ }^{114}$ Mexico, for example, in exchange for its commitment to the North American Free Trade Area (NAFTA), gained relatively few economic concessions from the United States and Canada. This has led many analysts to argue that NAFTA should be seen less as a quid pro quo and more as a means of establishing the credibility of the Mexican commitment to trade and economic liberalization against the future potential of backsliding. ${ }^{115}$ Mexican reform within NAFTA was just such a case where the three conditions were met: policy credibility was questionable, the consensus among foreign governments (the United States and Canada) was closer to the views of the domestic (Mexican) government than those of Mexican protectionists, and the costs of unilateral defection were perceived as large.

The process of European integration rested similarly on centralizing power in national executives, who consistently employed "foreign policy" decision-making institutions to handle issues traditionally decided in "domestic" forums. ${ }^{116}$ In this regard, the European Union has played the role in postwar European integration that a strong presidency and "fast track" institutions have played in securing postwar U.S. support for multilateral trade liberalization. In European monetary cooperation, weak-currency countries like France and Italy have been among the strongest proponents of deeper exchange-rate cooperation-often with the intention of using external policy to stabilize domestic macroeconomic policy and performance. As predicted, these examples tend to be cases in which a government whose views are relatively closer to those of the regional consensus employs international cooperation to "lock in" cooperation. This process is facilitated also by the independent ideological value of "Europe" in the minds of the Italian electorate, for example, and by the 
perception that monetary cooperation is linked to trade and agricultural cooperationboth of which shifted the perceived costs of defection. ${ }^{117}$

\section{Realism and Idealism in International Relations Theory}

The third and broadest implication of this analysis is that it counsels caution about the uncritical acceptance of certain ideational explanations for the emergence of international norms. Recent scholarship has been quick to assume that if realist (or regime) theory fails to explain international cooperation—say, in areas like human rights and environmental policy - the motivation for cooperation must lie in ideational socialization to altruistic beliefs. This assumption, once termed "idealist" or "utopian," seems plausible at first glance. The realist explanation for the emergence of human rights norms is manifestly weak. In a modern world increasingly dominated by liberal democratic practice, human rights seem salient and attractive ideals. Political action to protect them, moreover, clearly requires mobilizing a diffuse constituency in favor of the provision of what is in fact a public good, which in turn often requires that political actors issue strong normative appeals. Ideational theorists have little trouble finding public professions of moral conviction to support their view.

Yet scholars should not jump too quickly to the conclusion — as many recent studies of foreign aid, arms control, slavery, racism, and human rights invite them to do- that altruism must motivate the establishment of morally attractive international norms. ${ }^{118}$ The tendency to jump to this conclusion demonstrates the danger of conducting debates about world politics around the simple dichotomy of realism versus idealism (or realism versus constructivism), as seems the current norm. ${ }^{119}$ Presumptive evidence for the importance of altruistic or "principled" motivations vis-à-vis a realist account may melt away, as we have seen, as soon as the underlying theory is tested against more sophisticated rationalist, yet nonrealist (in this case, liberal) theories of self-interested political behavior. Moreover, to establish methodologically the existence of altruistic motivations and socialization processes, rather than alternative liberal theories, one must do more than cite public professions of idealism, document the actions of moral entrepreneurs, or invoke the desirability of the ultimate end. Talk and even mobilization are often cheap and often redundant or futile; accordingly, such evidence is often misleading. Cross-national comparison and primary-source documentation of decision making are the critical tests.

In the case of the establishment of the ECHR, the proper theory and method reverses an idealist conclusion that might appear to offer a plausible alternative to realism. ${ }^{120}$ What seems at first to be a conversion to moral altruism is in fact an instrumental calculation of how best to lock in democratic governance against future

117. See Frieden 1993; Collins 1988; Moravcsik 1998a, chap. 4, 6; and Krugman 1994, 189-94.

118. What drives cooperation is prior domestic institutional convergence. Hence the nature of domestic regimes is not an intermediate variable between fundamental socialization and state behavior but the critical variable that determines the nature of interdependence in the first place.

119. This is a view ideational theorists are coming to accept. Finnemore and Sikkink 1998, 916-17.

120. For example, Legro and Moravcsik 1999. 
opponents - a practice hardly distinct from similar practices in the most pecuniary areas of world politics, such as trade and monetary policy. I am not denying, of course, that ideas and ideals matter in foreign policy; I am challenging only a particular idealist argument. Surely some domestic support for democratic governance may be ideological, even idealistic, in origin. But if we can learn a single lesson from the formation of the world's most successful formal arrangement for international human rights enforcement, it is that in world politics pure idealism begets pure idealism-in the form of parliamentary assemblies and international declarations. To establish binding international commitments, much more is required.

\section{References}

Ackerman, Bruce. 1997. The Rise of World Constitutionalism. Virginia Law Review 83 (4):771-97.

Ando, Nisuke. 1992. The Future of Monitoring Bodies_Limitations and Possibilities of the Human Rights Committee. In 1991-1992 Canadian Human Rights Yearbook, 169-175. Toronto: Carswell.

Bailey, Michael A., Judith Goldstein, and Barry R. Weingast. 1997. The Institutional Roots of American Trade Policy: Politics, Coalitions, and International Trade. World Politics 49 (3):309-38.

Bass, Gary. 1998. Judging War: The Politics of International War Crimes Tribunals. Ph.D. diss., Harvard University.

Brett, Rachel. 1996. Human Rights and the OSCE. Human Rights Quarterly 18 (3):668-93.

Brysk, Alison. 1994. The Politics of Human Rights in Argentina: Protest, Change, and Democratization. Stanford, Calif.: Stanford University Press.

Carr, E. H. 1946. The Twenty Years' Crisis 1919-1939. 2d ed. London: Macmillan.

Carter, Barry E., and Phillip R. Trimble. 1995. International Law. 2d ed. Boston: Little, Brown.

Collins, Susan M. 1988. Inflation and the EMS. In The European Monetary System, edited by Francesco Giavazzi, Stefano Micossi, and Marcus Miller, 112-39. Cambridge: Cambridge University Press.

Costello, Declan. 1992. Limiting Rights Constitutionally. In Human Rights and Constitutional Law: Essays in Honour of Brian Walsh, edited by J. O'Reilly, 177-87. Dublin: Round Hall Press.

Council of Europe. 1975. Recueil des Travaux Préparatoires. 6 vols. Strasbourg: Council of Europe.

David, Stephen R. 1991. Explaining Third-World Alignment. World Politics 43 (2):233-56.

Dijk, Pieter van, and G. J. H. van Hoof. 1998. Theory and Practice of the European Convention on Human Rights. 3d ed. Hague: Kluwer.

Donnelly, Jack. 1986. International Human Rights: A Regime Analysis. International Organization 40 (3):599-642.

Doyle, Michael W. 1986. Liberalism and World Politics. American Political Science Review 80 (4): 1151-69.

Drzemczewski, Andrew Z. 1983. The European Human Rights Convention in Domestic Law: A Comparative Study. Oxford: Clarendon Press.

European Court of Justice. 1996. Opinion Pursuant to Article 228 of the Treaty. Opinion 2/94 (29 March): $\mathrm{I} / 1763-\mathrm{I} / 1790$.

Evans, Peter B., Harold K. Jacobson, and Robert D. Putnam. 1993. Double-Edged Diplomacy: International Bargaining and Domestic Politics. Berkeley: University of California Press.

Falk, Richard A. 1981. Human Rights and State Sovereignty. New York: Holmes and Meier.

Finnemore, Martha. 1996. National Interests in International Society. Ithaca, N.Y.: Cornell University Press.

Finnemore, Martha, and Kathryn Sikkink. 1998. International Norm Dynamics and Political Change. International Organization 52 (4):887-917.

Franck, Thomas M. 1988. Legitimacy in the International System. American Journal of International Law 82 (4):705-59. 
Frieden, Jeffry A. 1993. Making Commitments: France and Italy in the European Monetary System, 1979-1985. Working Paper Series 1.14. Berkeley, Calif.: Center for German and European Studies.

Glendon, Mary Ann. 1998a. Knowing the Universal Declaration of Human Rights. Notre Dame Law Review 73 (5):1153-90.

- 1998b. The Universal Declaration of Human Rights. Unpublished manuscript, Harvard Law School, Cambridge, Mass.

Goldstein, Judith. 1996. International Law and Domestic Institutions: Reconciling North American "Unfair"' Trade Laws. International Organization 50:541-64.

Haggard, Stephan. 1997. The Political Economy of Regionalism in Asia and the Americas. In The Political Economy of Regionalism, edited by Edward Mansfield and Helen Milner, 20-49. New York: Columbia University Press.

Helfer, Lawrence, and Anne-Marie Slaughter. 1997. Toward a Theory of Effective Supranational Adjudication. Yale Law Journal 107 (2):273-391.

Henkin, Louis, Gerald L. Neuman, Diane F. Orentlicher, and David W. Leebron. 1999. Human Rights. New York: Foundation Press.

Humphrey, John P. 1974. The Revolution in the International Law of Human Rights. Human Rights 4:205-16.

-1984. Human Rights and the United Nations: A Great Adventure. Dobbs Ferry: Transnational Publishers.

Huntington, Samuel. 1991. The Third Wave: Democratization in the Late Twentieth Century. Norman: University of Oklahoma Press.

Janis, Mark W., Richard S. Kay, and Anthony W. Bradley. 1995. European Human Rights Law: Text and Materials. Oxford: Clarendon Press.

Jepperson, Ronald L., Alexander Wendt, and Peter J. Katzenstein. 1996. Norms, Identity, and the Culture of National Security. In The Culture of National Security: Norms and Identity in World Politics, edited by Peter J. Katzenstein, 33-75. Ithaca, N.Y.: Cornell University Press.

Kaufman, Chaim D., and Robert A. Pape. 1999. Explaining Costly International Moral Action: Britain's Sixty-Year Campaign Against the Atlantic Slave Trade. International Organization 53 (4):631-68.

Keck, Margaret E., and Kathryn Sikkink. 1998. Activists Beyond Borders: Advocacy Networks in International Politics. Ithaca, N.Y.: Cornell University Press.

Keohane, Robert O. 1986. Theory of World Politics: Structural Realism and Beyond. In Neo-Realism and Its Critics, edited by Robert O. Keohane, 158-203. New York: Columbia University Press.

Krasner, Stephen D. 1992. Sovereignty and Intervention. Unpublished manuscript, Stanford University, Stanford, Calif.

1995. Compromising Westphalia. International Security 20 (3):115-51.

Krugman, Paul R. 1994. Peddling Prosperity: Economic Sense and Nonsense in the Age of Diminished Expectations. New York: Norton.

Kupchan, Charles A., and Clifford A. Kupchan. 1991. Concerts, Collective Security, and the Future of Europe. International Security 16 (1):114-61.

Lake, David A. 1993. Leadership, Hegemony, and the International Economy: Naked Emperor or Tattered Monarch with Potential? International Studies Quarterly 37 (4):459-89.

Landes, William M., and Richard A. Posner. 1975. The Independent Judiciary in an Interest-Group Perspective. Journal of Law and Economics 18 (3):875-901.

Legro, Jeffrey W. 1996. Culture and Preferences in the International Cooperation Two-Step. American Political Science Review 90 (1):118-37.

Legro, Jeffrey W., and Andrew Moravcsik. 1999. Is Anybody Still a Realist? International Security 24 (2):5-55.

Lester, Anthony. 1984. Fundamental Rights: The United Kingdom Isolated? In 1984 Public Law, edited by Graham Zellick, 46-72. London: Stevens and Sons.

- 1994. Taking Human Rights Seriously. King's College Law Journal 5:1-15.

Manas, Jean E. 1996. The Council of Europe's Democracy Ideal and the Challenge of Ethno-National Strife. In Preventing Conflict in the Post-Communist World: Mobilizing International and Regional 
Organizations, edited by Abram Chayes and Antonia Handler Chayes, 99-144. Washington, D.C.: Brookings Institution Press.

Marston, Geoffrey. 1993. The United Kingdom's Part in the Preparation of the European Convention on Human Rights, 1950. International and Comparative Law Quarterly 42 (4):796-826.

McKeon, Richard. 1949. The Philosophic Bases and Material Circumstances of the Rights of Man. In Human Rights: Comments and Interpretations, edited by UNESCO, 35-46. New York: UNESCO.

Merrills, J. G. 1993. The Development of International Law by the European Court of Human Rights. 2d ed. Manchester, U.K.: Manchester University Press.

Moe, Terry. 1990. Political Institutions: The Neglected Side of the Story. Journal of Law, Economics, and Organization 6 (1):213-53.

Moravcsik, Andrew. 1992. Liberalism and International Relations Theory. Center for International Affairs Working Paper Series 92-6. Cambridge, Mass.: Harvard University.

- 1994. Why the European Community Strengthens the State: International Cooperation and Domestic Politics. Center for European Studies Working Paper Series No. 52. Cambridge, Mass.: Harvard University.

- 1995. Explaining International Human Rights Regimes: Liberal Theory and Western Europe. European Journal of International Relations 1:157-89.

- 1997. Taking Preferences Seriously: A Liberal Theory of International Politics. International Organization 51 (4):513-53.

1998a. The Choice for Europe: Social Purpose and State Power from Messina to Maastricht. Ithaca, N.Y.: Cornell University Press.

- 1998b. The Origin of Human Rights Regimes: Liberal States and Domestic Uncertainty in Postwar Europe. Working Paper No. 98/17. Cambridge, Mass.: Weatherhead Center for International Affairs, Harvard University.

Morsink, Johannes. 1999. The Universal Declaration of Human Rights. Philadelphia: University of Pennsylvania Press.

Morgenthau, Hans J. 1960. Politics Among Nations: The Struggle for Power and Peace. 3d ed. New York: Alfred Knopf.

Nye, Joseph S., Jr. 1990. Bound to Lead: The Changing Nature of American Power. New York: Basic Books.

Pasquino, Pasquale. 1998. Constitutional Adjudication and Democracy: Comparative PerspectivesUSA, France, Italy. Ratio Juris 11:38-50.

Pierson, Paul. 1996. The Path to European Union: A Historical Institutionalist Analysis. Comparative Political Studies 29 (2):123-63.

Polakiewicz, Jörg, and Valérie Jacob-Foltzer. 1991. The European Human Rights Convention in Domestic Law: The Impact of Strasbourg Case Law in States Where Direct Effect Is Given to the Convention. Human Rights Law Quarterly 12:65-85, 125-142.

Putnam, Robert D. 1988. Diplomacy and Domestic Politics. International Organization 42 (3): 427-61.

Ramirez, Francisco O., Yasemin Soysal, and Suzanne Shanahan. 1997. The Changing Logic of Political Citizenship: Cross-National Acquisition of Women's Suffrage Rights, 1890-1990. American Sociological Review 62 (5):735-45.

Risse, Thomas. 2000. Let's Argue! Communicative Action and International Relations. International Organization 54 (1):1-39.

Risse-Kappen, Thomas. 1994. Ideas Do Not Float Freely: Transnational Coalitions, Domestic Structures, and the End of the Cold War. International Organization 48 (2):185-214.

- 1996. Collective Identity in a Democratic Community: The Case of NATO. In The Culture of National Security: Norms and Identity in World Politics, edited by Peter J. Katzenstein, 357-99. New York: Columbia University Press.

Robertson, A. H., and J. G. Merrills. 1993. Human Rights in Europe: A Study of the European Convention on Human Rights. 3d ed. Manchester, U.K.: Manchester University Press.

-1996. Human Rights in the World: An Introduction to the International Protection of Human Rights. 4th ed. Manchester, U.K.: Manchester University Press.

Rodrik, Dani. 1989. Credibility of Trade Reform: A Policy Maker's Guide. World Economy 12 (1):1-16. 
Ruggie, John Gerard. 1983. Human Rights and the Future International Community. Daedalus 112 (4):93110.

Russett, Bruce. 1993. Grasping the Democratic Peace: Principles for a Post-Cold War World. Princeton, N.J.: Princeton University Press.

Samnøy, Åshild. 1993. Human Rights as International Consensus: The Making of the Universal Declaration of Human Rights, 1945-1948. Bergen: Michelsen Institute.

Shapiro, Martin. 1981. Courts: A Comparative and Political Analysis. Chicago: University of Chicago Press.

Sieghart, Paul. 1983. The International Law of Human Rights. Oxford: Clarendon Press.

Sikkink, Kathryn. 1993. The Power of Principled Ideas: Human Rights Policies in the United States and Western Europe. In Ideas and Foreign Policy: Beliefs, Institutions, and Political Change, edited by Judith Goldstein and Robert O. Keohane, 139-70. Ithaca, N.Y.: Cornell University Press.

Simpson, A. W. Brian. 1998. Short History of the European Convention on Human Rights. Unpublished manuscript, University of Michigan Law School, Ann Arbor.

Slaughter, Anne-Marie, Alec Stone Sweet, and Joseph H. H. Weiler, eds. 1998. The European Court and National Courts: Doctrine and Jurisprudence . Oxford: Hart Publishing.

Snyder, Jack. 1991. Myths of Empire: Domestic Politics and International Ambition. Ithaca, N.Y.: Cornell University Press.

Teitgen, Pierre-Henri. 1988. Faites entrer le tèmoin suivant 1940-1958: de la résistance à la Ve République. Rennes, France: Ouest-France.

Van Evera, Stephen. 1990. Primed for Peace. International Security 15 (winter):7-57.

- 1999. The Causes of War: Power and the Roots of Conflict. Ithaca, N.Y.: Cornell University Press.

Waltz, Kenneth N. 1979. Theory of International Politics. Reading, Mass.: Addison-Wesley.

Wippman, David. 1999. Practical and Legal Constraints on Internal Power Sharing. In International Relations and Ethnic Conflict, edited by David Wippman, 170-88. Ithaca, N.Y.: Cornell University Press.

Whitfield, John H. 1988. How the Working Organs of the European Convention Have Elevated the Individual to the Level of Subject of International Law. ILSA Journal of International Law 12:27-53. 